\title{
PENGARUH PENAMBAHAN TERUNG BELANDA (Solanum betaceum Cav.) TERHADAP KARAKTERISTIK MARSHMALLOW
}

\author{
Ni Putu Anita Devi ${ }^{1)}$, Putu Ari Sandhi Wipradnyadewi ${ }^{2)}$, Ni Made Yusa ${ }^{2)}$ \\ ${ }^{1)}$ Mahasiswa Ilmu dan Teknologi Pangan, Fakultas Teknologi Pertanian, Universitas Udayana \\ ${ }^{2)}$ Dosen Ilmu dan Teknologi Pangan, Fakultas Teknologi Pertanian, Universitas Udayana
}

Email : devianita70@ymail.com

\begin{abstract}
The aim of this research is to know the effect of the addition of tamarillo (Solanum betaceum Cav) to marshmallow characteristic, and to determine the addition of the best tamarillo to produce the best characteristic marshmallow. The experimental design used was Completely Randomized Design (RAL) by treatment with fruit pulp tamarillo as follows: $30 \%, 40 \%, 50 \%, 60 \%, 70 \%$ and $80 \%$. Each treatment was repeated three times to obtain 18 experimental units. The results showed that the addition of tamarillo showed significant effect on water content, ash content, total anthocyanin, vitamin C, total sugar, elasticity, color score test, taste score test, texture score test, aroma and overall acceptance and no significant effect on color hedonic test and taste hedonic test. The best characteristic of marshmallow was obtained from the addition of tamarillo of $30 \mathrm{~g}$ with water content of $19.44 \%$, ash content of $0.08 \%$, total anthocyanin $0.44 \mathrm{mg} / \mathrm{L}$, vitamin C $8.20 \mathrm{mg}$ / $100 \mathrm{~g}$, total sugar $75.15 \%$, elasticity of $1.47 \mathrm{~N}$, color (rather pink and rather like), aroma (rather like), texture (very chewy and like), taste (sweet and rather like), overall acceptance (like).
\end{abstract}

Keywords : Tamarillo, Marshmallow, Characteristic, Anthocyanin

\section{PENDAHULUAN}

Marshmallow adalah makanan ringan bertekstur seperti busa yang lembut dalam berbagai bentuk, aroma dan warna. Marshmallow bila dimakan meleleh di dalam mulut karena merupakan hasil dari campuran gula atau sirup jagung, gelatin, dan bahan perasa yang dikocok hingga mengembang (Nakai dan Modler, 1999). Marshmallow memiliki warna, rasa dan bentuk yang beraneka ragam, tetapi tidak dapat dipastikan bahwa warna, rasa, dan aroma yang ditambahkan merupakan buah asli atau tidak (Ginting et al., 2014). Ditinjau dari segi gizi, marshmallow mengandung karbohidrat, protein, lemak, serta mineral dan pada umumnya marshmallow tidak mengandung antosianin (Anon., 2013).

Selain zat gizi, warna dan rasa juga mempengaruhi daya tarik konsumen terhadap suatu produk. Salah satu upaya produsen untuk mempertahankan daya tarik konsumen terhadap marshmallow adalah dengan menambahkan pewarna dan perasa sintetis ke dalam produksi marshmallow sehingga marshmallow yang dihasilkan memiliki warna dan rasa yang menarik. Namun, penggunaan pewarna dan perasa sintetis yang tidak sesuai takaran yang ditentukan akan memberikan dampak negatif. Oleh sebab itu, akan lebih baik apabila pewarna dan perasa sintetis yang digunakan diganti dengan pewarna dan perasa alami yang diperoleh dari bahan alami seperti terung belanda.

Terung belanda (Solanum betaceum Cav.) merupakan tanaman yang sangat terkenal di New Zealand. Terung belanda dalam setiap 100 gram bagian yang dapat dimakan mengandung air 80 - $90 \mathrm{~g}$, protein 1,4 - 2 mg, lemak 0,1 - 0,6 mg, karbohidrat 10,3 gram, serat $1,4-4,7 \mathrm{mg}$, vitamin A 540 - 
$5600 \mu \mathrm{g}$, vitamin E $2 \mathrm{mg}$ dan vitamin C 15 42 mg (Kumalaningsih dan Suprayogi, 2006). Terung Belanda mengandung antosianin yang termasuk kedalam golongan flavonoid yang merupakan salah satu jenis antioksidan, serat yang tinggi di dalam buahnya bermanfaat untuk mencegah kanker dan sembelit. Antosianin tersebut dapat dimanfaatkan sebagai pewarna makanan atau minuman. Antosianin terung belanda merupakan sumber antioksidan alami yang dapat digunakan untuk memperkecil reaksi oksidasi dan menangkal radikal bebas (Hernani dan Rahardjo, 2005). Pigmen antosianin yang terkandung dalam terung belanda dapat dijadikan sebagai salah satu alternatif pewarna alami (Diniyah et al., 2010).

Terung belanda diharapkan dapat digunakan sebagai bahan baku dalam pembuatan marshmallow, karena mempunyai kandungan gizi yang baik. Selain itu, buah terung belanda jarang dihidangkan sebagai buah meja karena rasanya yang cenderung asam. Rasa asam yang sangat tinggi dari buah terung belanda menyebabkan banyak orang tidak suka mengkonsumsi buah tersebut dalam keaadaan segar sehingga diperlukan upaya untuk mengolah buah terung belanda seperti dijadikan marshmallow (Budi, 2006). Penambahan terung belanda dalam pembuatan marshmallow dapat digunakan untuk membantu meningkatkan nilai gizi serta konsumsi pangan yang lebih bervariasi bagi masyarakat luas. Berdasarkan latar belakang tersebut, maka perlu dilakukan penelitian tentang pengaruh penambahan terung belanda pada pembuatan marshmallow. Tujuan dari penelitian ini adalah mengetahui pengaruh penambahan terung belanda terhadap karakteristik marshmallow dan mengetahui penambahan terung belanda yang tepat untuk menghasilkan karakteristik marshmallow yang terbaik.

\section{METODE PENELITIAN}

Tempat dan Waktu Penelitian

Penelitian ini dilaksanakan di Laboratorium Pengolahan Pangan, Laboratorium Analisis Pangan, Laboratorium Teknologi Pascapanen Fakultas Teknologi Pertanian, dan Laboraturium Tanah Fakultas Pertanian mulai bulan Desember 2016 sampai dengan bulan Februari 2017.

\section{Alat dan Bahan}

Alat-alat yang digunakan untuk pembuatan marshmallow terung belanda adalah pisau, waskom, blender, panci, termometer, sendok, talenan, pangaduk, kompor, mixer, cetakan, sedangkan alat yang digunakan untuk analisis meliputi oven merk Cole Palmer-Stable, muffle, timbangan analitik merk Methler Toledo AB-204, kertas saring Whatman, pipet tetes, pipet volume, spektrofotometer (unico UV-2100), texture analyzer, Erlenmeyer merk Pyrex, cawan porselin, tabung reaksi, batang pengaduk, eksikator, corong, labu takar merk Pyrex, gelas ukur merk Pyrex, gelas beker, vortex, aluminium foil dan texture analyzer.

Bahan-bahan yang digunakan dalam penelitian ini adalah terung belanda tipe merah, tingkat kematangan optimal berwarna merah penuh merata yang diperoleh di pasar 
Badung, gula pasir merk lokal, sirup glukosa merk prambanan kencana dan gelatin (semua bahan dibeli di UD. Feny Jl. Kartini Denpasar). Bahan-bahan kimia yang digunakan yaitu, aquades, metanol, HCL, $\mathrm{NaOH}$, asam sitrat, natrium sitrat, $\mathrm{KI}$, amilum, iod, natrium karbonat anhidrat, garam Rochelle, natrium bikarbonat, natrium sulfat anhidrat, $\mathrm{CuSO}_{4} \mathrm{H}_{2} \mathrm{O}$, glukosa anhidrat dan arsenomolibidat.

\section{Rancangan Penelitian}

Penelitian ini menggunakan Rancangan Acak Lengkap (RAL) dengan perlakuan penambahan bubur buah terung belanda yang digunakan, yaitu $: \mathrm{P} 1=30 \%, \mathrm{P} 2=40 \%, \mathrm{P} 3=$ $50 \%, \mathrm{P} 4=60 \%, \mathrm{P} 5=70 \%, \mathrm{P} 6=80 \%$. Persentase penambahan bubur buah terung belanda diambil dari total jumlah gelatin, gula pasir, sirup glukosa dan air yang ditambahkan. Masing-masing perlakuan diulang sebanyak 3 kali sehingga diperoleh 18 unit percobaan untuk masing-masing penelitian. Data yang diperoleh akan dianalisis dengan sidik ragam dan apabila terdapat pengaruh perlakuan terhadap parameter yang diamati, maka dilanjutkan dengan uji Duncan (Harsojuwono et al., 2011).

\section{Variabel yang Diamati}

Variabel yang diamati pada penelitian ini adalah kadar air dengan metode pengeringan (Sudarmadji et al., 1997), kadar abu dengan metode pengabuan (Sudarmadji et al., 1997), Total gula dengan metode nelsonsomogy (Sudarmadji., et al 1997), total antosianin dengan metode $\mathrm{pH}$ differential (Giusti dan Wrolstad, 2001), kadar vitamin C dengan metode iodometri (Sudarmadji et al., 1997), Uji kekenyalan dengan alat texture analyzer (Nur, 2009 dalam Syukroni et al., 2013) dan evaluasi sensori yang meliputi rasa, aroma, tekstur, warna, dan penerimaan keseluruhan dengan metode uji skoring dan uji hedonik (Soekarto, 1985).

\section{Pelaksanaan Penelitian}

Persiapan bahan-bahan yang digunakan dalam pembuatan marshmallow terung belanda yaitu terung belanda, gelatin, gula pasir, sirup glukosa dan air. Bahan yang digunakan kemudian ditimbang sesuai dengan formulasinya. Formulasi marshmallow dapat dilihat pada Tabel 1.

Tabel 1. Formulasi marshmallow

\begin{tabular}{|c|c|c|c|c|c|c|c|}
\hline \multirow[t]{2}{*}{ No } & \multirow[t]{2}{*}{ Komposisi Bahan } & \multicolumn{6}{|c|}{ Perlakuan } \\
\hline & & P1 & $\mathrm{P} 2$ & P3 & P4 & P5 & P6 \\
\hline 1. & Bubur buah terung belanda $(\mathrm{g})$ & 30 & 40 & 50 & 60 & 70 & 80 \\
\hline 2. & Gelatin (g) & 3,5 & 3,5 & 3,5 & 3,5 & 3,5 & 3,5 \\
\hline 3. & Gula pasir (g) & 54 & 54 & 54 & 54 & 54 & 54 \\
\hline 4. & Sirup glukosa (g) & 30 & 30 & 30 & 30 & 30 & 30 \\
\hline 5. & Air (ml) & 12,5 & 12,5 & 12,5 & 12,5 & 12,5 & 12,5 \\
\hline
\end{tabular}

Pembuatan marshmallow dimulai dengan kulit buah terung belanda dikupas, buah dipotong dan dihancurkan menggunakan blender dengan perbandingan buah dan air ( 1 : $1 / 2$ ) yang menghasilkan bubur buah. Bubur buah terung belanda kemudian disaring untuk 
menghilangkan bijinya. Bubur buah yang telah disaring dipanaskan pada suhu $80{ }^{\circ} \mathrm{C}$ selama 5 menit. Bubur buah yang telah dipanaskan ditimbang sesuai perlakuan sebanyak 30 g, 40 g, 50 g, 60 g, 70 g, 80 g. Gelatin ditimbang sebanyak 3,5 g dilarutkan dengan bubur buah yang telah dipanaskan maka, dihasilkan larutan bubur buah terung belanda dan gelatin selanjutnya, timbang gula pasir (54 g), sirup glukosa (30 g) dan air (12,5 ml) dipanaskan sampai suhu $112{ }^{\mathrm{O}} \mathrm{C}$ sehingga dihasilkan larutan gula. Larutan gula dan larutan bubur buah terung belanda serta gelatin dicampur menjadi satu kemudian dikocok menggunakan mixer hingga homogen dan mengembang selama 15 menit setelah itu, dilanjutkan dengan penuangan pada cetakan lalu didiamkan pada suhu ruang selama 24 jam sampai memadat, setelah memadat dikeluarkan dari cetakan dan dipotong-potong.

\section{HASIL DAN PEMBAHASAN}

Hasil analisis kadar air, kadar abu, total antosianin, vitamin $\mathrm{C}$, dan total gula, disajikan pada Tabel 2.

Tabel 2. Nilai rata-rata kadar air, kadar abu, total antosianin, vitamin C, dan total gula marshmallow

\begin{tabular}{cccccc}
\hline \multirow{2}{*}{ Perlakuan } & \multicolumn{5}{c}{ Nilai rata - rata } \\
\cline { 2 - 6 } & $\begin{array}{c}\text { Kadar air } \\
(\%)\end{array}$ & $\begin{array}{c}\text { Kadar abu } \\
(\%)\end{array}$ & $\begin{array}{c}\text { Total } \\
\text { Antosianin } \\
(\mathrm{mg} / \mathrm{L})\end{array}$ & $\begin{array}{c}\text { Vitamin C } \\
(\mathrm{mg} / 100 \mathrm{~g})\end{array}$ & Total gula (\%) \\
\hline P1 (30\%) & $19,44 \mathrm{a}$ & $0,08 \mathrm{a}$ & $0,44 \mathrm{a}$ & $8,20 \mathrm{a}$ & $75,15 \mathrm{e}$ \\
P2 (40\%) & $20,03 \mathrm{~b}$ & $0,19 \mathrm{ab}$ & $1,39 \mathrm{a}$ & $10,34 \mathrm{ab}$ & $69,28 \mathrm{~d}$ \\
P3 (50\%) & $20,55 \mathrm{c}$ & $0,23 \mathrm{bc}$ & $3,00 \mathrm{~b}$ & $11,42 \mathrm{ab}$ & $66,34 \mathrm{~cd}$ \\
P4 (60\%) & $21,42 \mathrm{~d}$ & $0,32 \mathrm{bc}$ & $3,17 \mathrm{~b}$ & $12,97 \mathrm{bc}$ & $61,34 \mathrm{bc}$ \\
P5 (70\%) & $21,71 \mathrm{~d}$ & $0,34 \mathrm{~cd}$ & $5,34 \mathrm{c}$ & $15,28 \mathrm{c}$ & $59,10 \mathrm{ab}$ \\
P6 (80\%) & $23,52 \mathrm{e}$ & $0,47 \mathrm{~d}$ & $6,18 \mathrm{c}$ & $15,54 \mathrm{c}$ & $55,10 \mathrm{a}$ \\
\hline
\end{tabular}

Keterangan : Nilai rata-rata yang diikuti oleh huruf yang berbeda pada kolom sama menunjukkan perbedaan yang nyata $(\mathrm{P}<0,05)$

\section{Kadar Air}

Hasil analisis ragam menunjukkan bahwa perlakuan penambahan bubur buah terung belanda berpengaruh sangat nyata $(\mathrm{P}<0,01)$ terhadap kadar air marshmallow. Pada Tabel 2 kadar air marshmallow berkisar antara $19,44 \%$ sampai dengan $23,52 \%$. Kadar air tertinggi diperoleh dari perlakuan P6 yaitu 23,52\%, sedangkan kadar air terendah diperoleh pada perlakuan P1 yaitu 19,44\%. Sartika (2009) menyatakan bahwa marshmallow komersial memiliki kadar air sebesar $16,84 \%$. Semakin banyak penambahan bubur buah terung belanda menyebabkan kadar air marshmallow semakin meningkat. Hal ini disebabkan karena kandungan air pada terung belanda yang cukup tinggi yaitu berkisar 80 90 g/100g (Kumalaningsih dan Suprayogi, 2006). Wati (2003) menyatakan bahwa jika buah yang ditambahkan mengandung banyak air maka akan berpengaruh terhadap peningkatan kadar air produk akhir, semakin banyak persentase buah yang digunakan maka semakin tinggi kadar air produknya. Pada perlakuan P1 yang diteliti memiliki kadar air 
yang memenuhi syarat mutu permen lunak dari SNI yaitu maksimal 20\% (bb) (Anon., 2008).

\section{Kadar abu}

Hasil analisis ragam terhadap kadar abu marshmallow menunjukkan bahwa perlakuan penambahan bubur buah terung belanda berpengaruh sangat nyata $(\mathrm{P}<0,01)$ terhadap kadar abu marshmallow. Pada Tabel 2 kadar abu marshmallow berkisar antara 0,08\% sampai dengan $0,47 \%$. Kadar abu tertinggi diperoleh dari perlakuan P6 yaitu 0,47\%, sedangkan kadar abu terendah diperoleh dari perlakuan P1 yaitu 0,08 \%. Sartika (2009) menyatakan bahwa marshmallow komersial memiliki kadar abu sebesar 0,10\%. Semakin banyak penambahan bubur buah terung belanda maka kadar abu marshmallow semakin meningkat, hal ini disebabkan dalam terung belanda terdapat kandungan mineral seperti kalsium 6-18 $\mathrm{mg} / 100 \mathrm{~g}$ dan besi 0,3-0,9 $\mathrm{mg} / 100 \mathrm{~g}$. Kadar abu juga dikenal dengan unsur mineral yang berfungsi sebagai zat pembangun dan pengatur (Winarno, 2004). Pada seluruh perlakuan yang diteliti memiliki kadar abu yang memenuhi syarat mutu permen lunak dari SNI yaitu maksimal 3 \% (bb) (Anon., 2008).

\section{Total antosianin}

Hasil analisis ragam menunjukkan bahwa perlakuan penambahan bubur buah terung belanda berpengaruh sangat nyata $(\mathrm{P}<0,01) \quad$ terhadap kadar antosianin marshmallow. Pada Tabel 2 total antosianin marshmallow berkisar antara $0,44 \mathrm{mg} / \mathrm{L}$ sampai dengan $6,18 \mathrm{mg} / \mathrm{L}$. Total antosianin tertinggi diperoleh dari perlakuan P6 yaitu 6,18 $\mathrm{mg} / \mathrm{L}$ sedangkan kadar antosianin terendah diperoleh dari perlakuan P1 yaitu $0,44 \mathrm{mg} / \mathrm{L}$. Semakin banyak penambahan bubur buah terung belanda total antosianin pada marshmallow yang dihasilkan juga semakin tinggi, hal ini dikarenakan peningkatan total antosianin berbanding lurus dengan penambahan bubur buah terung belanda. Menurut Arinaldo (2011) ekstrak terung belanda memiliki total antosianin $1478 \mathrm{mg} / \mathrm{L}$, antosianin termasuk ke dalam golongan flavonoid yang merupakan salah satu jenis antioksidan. Antosianin tersebut dapat dimanfaatkan sebagai pewarna makanan atau minuman. Marshmallow yang dibuat dengan menggunakan terung belanda memiliki kandungan gizi yang lebih baik dibandingkan dengan marshmallow yang dibuat tanpa menggunakan terung belanda.

\section{Vitamin C}

Hasil analisis ragam terhadap kadar vitamin $\mathrm{C}$ marshmallow menunjukkan bahwa perlakuan penambahan bubur buah terung belanda berpengaruh sangat nyata $(\mathrm{P}<0,01)$ terhadap kadar vitamin $\mathrm{C}$ marshmallow. Pada Tabel 2 kadar vitamin C marshmallow berkisar antara $8,20 \mathrm{mg} / 100 \mathrm{~g}$ sampai dengan 15,54 $\mathrm{mg} / 100 \mathrm{~g}$. Vitamin $\mathrm{C}$ tertinggi diperoleh dari perlakuan P6 yaitu 15,54 mg/100g, sedangkan vitamin $\mathrm{C}$ terendah diperoleh dari perlakuan P1 yaitu $8.20 \mathrm{mg} / 100 \mathrm{~g}$. Semakin banyak penambahan bubur buah terung belanda kandungan vitamin $\mathrm{C}$ pada marshmallow yang dihasilkan juga semakin tinggi. Peningkatan kandungan vitamin $\mathrm{C}$ berbanding lurus dengan penambahan bubur buah terung belanda. Hal 
ini disebabkan karena kandungan vitamin $\mathrm{C}$ pada terung belanda yang cukup tinggi yaitu berkisar $15-42 \mathrm{mg} / 100 \mathrm{~g}$ (Kumalaningsih dan Suprayogi, 2006).

\section{Total gula}

Hasil analisis ragam terhadap total gula marshmallow menunjukkan bahwa perlakuan penambahan bubur buah terung belanda berpengaruh sangat nyata $(\mathrm{P}<0,01)$ terhadap total gula marshmallow. Pada Tabel 2 total gula marshmallow berkisar antara 55,10\% sampai dengan 75,14\%. Total gula tertinggi diperoleh dari perlakuan P1 yaitu 75,15\%, sedangkan total gula terendah diperoleh dari perlakuan P6 yaitu 55,10 \%. Semakin banyak penambahan bubur buah terung belanda total gula pada marshmallow yang dihasilkan juga semakin menurun. Silaban et al., (2013) menyatakan bahwa kadar gula pada terung belanda yaitu 1,5\%. Hal ini sesuai dengan penelitian Bangun, (2010) yang menyatakan bahwa kandungan gula terung belanda sedikit, sehingga semakin banyak terung belanda yang digunakan pada perlakuan, maka total gula akan semakin menurun. Luthony, (1990) dalam Pratama et al., (2013) menyatakan bahwa total gula akan mengalami peningkatan jika jumlah gula yang diberikan juga semakin besar. Apabila jumlah gula tetap dan penambahan buah yang mengandung asam lebih banyak maka total gula mengalami penurunan.

\section{Kekenyalan}

Hasil rata-rata kekenyalan marshmallow terung belanda dapat dilihat pada Tabel 3 .

Tabel 3. Nilai rata - rata uji kekenyalan marshmallow

Perlakuan Kekenyalan (N)

\begin{tabular}{cc}
\hline P1 $(30 \%)$ & $1,47 \mathrm{~d}$ \\
P2 $(40 \%)$ & $0,76 \mathrm{c}$ \\
P3 $(50 \%)$ & $0,59 \mathrm{bc}$ \\
P4 $(60 \%)$ & $0,35 \mathrm{ab}$ \\
P5 $(70 \%)$ & $0,34 \mathrm{ab}$ \\
P6 (80\%) & $0,27 \mathrm{a}$ \\
\hline
\end{tabular}

Keterangan : Nilai rata-rata yang diikuti oleh huruf yang berbeda pada kolom sama menunjukkan perbedaan yang nyata $(\mathrm{P}<0,05)$

Hasil analisis ragam terhadap kekenyalan marshmallow menunjukkan bahwa perlakuan penambahan bubur buah terung belanda berpengaruh sangat nyata $(\mathrm{P}<0,01)$ terhadap kekenyalan marshmallow. Pada tabel 3 menunjukkan bahwa kekenyalan marshmallow ini berkisar antara 0,27 $\mathrm{N}$ hingga 1,47 N. Nilai rata-rata kekenyalan marshmallow tertinggi diperoleh pada perlakuan $\mathrm{P} 1$ yaitu $1,47 \mathrm{~N}$, sedangkan nilai rata-rata kekenyalan marshmallow terendah diperoleh pada perlakuan P6 yaitu 0,27 N. Semakin meningkat penambahan bubur buah terung belanda maka kekenyalan marshmallow semakin menurun. Kekenyalan merupakan salah satu faktor yang penting dalam menentukan mutu sebuah marshmallow. Kekenyalan dapat dipengaruhi oleh kadar air 
marshmallow yang dihasilkan. Terung belanda memiliki kadar air yang tinggi sehingga dapat mempengaruhi kekenyalan marshmallow yang dihasilkan (Malik, 2010 dalam Fitrina, 2014).

Sifat sensoris
Evaluasi sifat sensoris marshmallow dilakukan terhadap warna, aroma, tekstur, rasa dan penerimaan keseluruhan. Nilai rata-rata hasil analisis terhadap warna, aroma, tekstur, rasa dan penerimaan keseluruhan marshmallow dapat dilihat pada Tabel 4.

Tabel 4. Nilai rata-rata uji skoring dan uji hedonik terhadap warna, tekstur, aroma, rasa, dan penerimaan keseluruhan marshmallow

\begin{tabular}{|c|c|c|c|c|c|c|c|c|}
\hline \multirow{3}{*}{ Perlakuan } & \multicolumn{8}{|c|}{ Nilai rata - rata } \\
\hline & \multicolumn{2}{|c|}{ Warna } & \multirow{2}{*}{$\begin{array}{c}\text { Aroma } \\
\text { Hedonik }\end{array}$} & \multicolumn{2}{|c|}{ Tekstur } & \multicolumn{2}{|c|}{ Rasa } & \multirow{2}{*}{$\begin{array}{c}\text { Penerimaan } \\
\text { keseluruhan } \\
\text { Hedonik }\end{array}$} \\
\hline & Skoring & Hedonik & & Skoring & Hedonik & Skoring & Hedonik & \\
\hline P1 $(30 \%)$ & $1,67 \mathrm{a}$ & $4,33 a$ & $4,33 \mathrm{a}$ & $4,67 \mathrm{e}$ & $5,73 c$ & $4,87 \mathrm{c}$ & $4,93 \mathrm{a}$ & $5,60 \mathrm{c}$ \\
\hline P2 $(40 \%)$ & $2,33 b$ & $5,14 \mathrm{a}$ & $4,87 \mathrm{ab}$ & $3,87 \mathrm{~d}$ & $5,00 \mathrm{bc}$ & $4,80 \mathrm{c}$ & $4,93 \mathrm{a}$ & $5,73 c$ \\
\hline P3 $(50 \%)$ & $2,60 \mathrm{bc}$ & $4,80 \mathrm{a}$ & $5,00 \mathrm{abc}$ & $3,93 d$ & $4,73 b c$ & $4,53 \mathrm{c}$ & $4,87 \mathrm{a}$ & $5,47 b c$ \\
\hline P4 (60\%) & $3,07 \mathrm{c}$ & $4,00 \mathrm{a}$ & $5,27 \mathrm{bcd}$ & $3,40 \mathrm{c}$ & $4,40 \mathrm{ab}$ & $4,00 \mathrm{~b}$ & $4,93 a$ & $4,80 \mathrm{ab}$ \\
\hline P5 (70 \%) & $3,67 d$ & $4,60 \mathrm{a}$ & $5,67 \mathrm{~cd}$ & $3,00 \mathrm{~b}$ & $4,27 \mathrm{ab}$ & $3,47 \mathrm{a}$ & $5,00 \mathrm{a}$ & $4,80 \mathrm{ab}$ \\
\hline P6 $(80 \%)$ & $4,00 \mathrm{~d}$ & $5,07 \mathrm{a}$ & $5,80 \mathrm{~d}$ & $2,00 \mathrm{a}$ & $3,67 \mathrm{a}$ & $3,13 \mathrm{a}$ & $5,67 \mathrm{a}$ & $4,67 \mathrm{a}$ \\
\hline
\end{tabular}

Keterangan : nilai rata-rata yang diikuti oleh huruf yang berbeda pada kolom sama menunjukkan perbedaan yang nyata $(\mathrm{P}<0,05)$

\section{Warna}

Hasil analisis ragam uji skoring marshmallow menunjukkan bahwa pengaruh penambahan bubur buah terung belanda berpengaruh sangat nyata $(\mathrm{P}<0,01)$ terhadap warna marshmallow. Tabel 4 menunjukkan bahwa nilai rata-rata skor tertinggi terhadap warna marshmallow berkisar antara 1,67 (agak merah muda) sampai dengan 4,00 (merah). Nilai rata-rata skor tertinggi diperoleh pada perlakuan P6 yaitu 4,00 (merah), sedangkan nilai rata-rata terendah diperoleh pada perlakuan P1 yaitu 1,67 (agak merah muda).Hasil analisis ragam uji hedonik marshmallow menunjukkan bahwa pengaruh penambahan bubur buah terung belanda berpengaruh tidak nyata terhadap warna marshmallow. Tabel 4 menunjukkan bahwa nilai rata-rata tingkat kesukaan panelis terhadap warna marshmallow berkisar antara 4,00 (biasa) sampai dengan 5,14 (agak suka). Nilai rata-rata tertinggi kesukaan panelis terhadap warna marshmallow diperoleh pada perlakuan P2 yaitu 5,14 (agak suka), sedangkan nilai rata-rata terendah diperoleh pada perlakuan P4 yaitu 4,00 (biasa). Penerimaan panelis terhadap warna marshmallow semakin meningkat dengan semakin banyak penambahan bubur buah terung belanda. Semakin banyak penambahan bubur buah terung belanda dapat meningkatkan total antosianin ke dalam produk tersebut sehingga menyebabkan warna marshmallow menjadi lebih merah.

\section{Aroma}

Hasil analisis ragam uji hedonik marshmallow menunjukkan bahwa pengaruh penambahan bubur buah terung belanda 
berpengaruh sangat nyata $(\mathrm{P}<0,01)$ terhadap aroma marshmallow. Tabel 4 menunjukkan bahwa nilai rata-rata tingkat kesukaan panelis terhadap aroma marshmallow berkisar antara 4,33 (biasa) sampai dengan 5,80 (suka). Nilai rata-rata tertinggi kesukaan panelis terhadap warna marshmallow diperoleh pada perlakuan P6 yaitu 5,80 (suka), sedangkan nilai rata-rata terendah diperoleh pada perlakuan P1 yaitu 4,33 (biasa). Penerimaan panelis terhadap aroma marshmallow semakin meningkat dengan semakin banyak penambahan bubur buah terung belanda.

\section{Tekstur}

Hasil analsis ragam uji skoring marshmallow menunjukkan bahwa pengaruh penambahan bubur buah terung belanda berpengaruh sangat nyata $(\mathrm{P}<0,01)$ terhadap tekstur marshmallow. Tabel 4 menunjukkan bahwa nilai rata-rata skor tertinggi terhadap tekstur marshmallow berkisar antara 2,00 (agak tidak kenyal) sampai dengan 4,67 (sangat kenyal). Nilai rata-rata skor tertinggi diperoleh pada perlakuan P1 yaitu 4,67 (sangat kenyal), sedangkan nilai rata-rata terendah diperoleh pada perlakuan P6 yaitu 2,00 (agak tidak kenyal). Hasil analisis ragam uji hedonik marshmallow menunjukkan bahwa pengaruh penambahan bubur buah terung belanda berpengaruh sangat nyata $(\mathrm{P}<0,01)$ terhadap tekstur marshmallow. Tabel 4 menunjukkan bahwa nilai rata-rata tingkat kesukaan panelis terhadap tekstur marshmallow berkisar antara 3,67 (biasa) sampai dengan 5,73 (suka). Nilai rata-rata tertinggi diperoleh pada perlakuan $\mathrm{P} 1$, sedangkan nilai rata-rata terendah diperoleh pada perlakuan P4 yaitu 4,00 (biasa). Tekstur marshmallow dipengaruhi oleh adanya penggunaan terung belanda dalam pembuatan marshmallow. Terung belanda memiliki kadar air yang tinggi sehingga menghasilkan marshmallow dengan kadar air tinggi yang dapat mempengaruhi tekstur marshmallow yang dihasilkan.

\section{Rasa}

Hasil analsis ragam uji skoring marshmallow menunjukkan bahwa pengaruh penambahan bubur buah terung belanda berpengaruh sangat nyata $(\mathrm{P}<0,01)$ terhadap rasa marshmallow. Tabel 4 menunjukkan bahwa nilai rata-rata skor terhadap rasa marshmallow berkisar antara 3,13 (agak manis) sampai dengan 4,87 (manis). Nilai ratarata skor tertinggi diperoleh pada perlakuan P1 yaitu 4,87 (manis), sedangkan nilai rata-rata terendah diperoleh pada perlakuan P6 yaitu 3,13 (agak asam). Hasil analisis ragam uji hedonik marshmallow menunjukkan bahwa pengaruh penambahan bubur buah terung belanda berpengaruh tidak nyata terhadap rasa marshmallow. Tabel 4 menunjukkan bahwa nilai rata-rata tingkat kesukaan panelis terhadap rasa marshmallow berkisar antara 4,93 (agak suka) sampai dengan 5,67 (suka). Nilai rata-rata tertinggi diperoleh pada perlakuan P6 yaitu 5,67 (suka), sedangkan nilai rata-rata terendah diperoleh pada perlakuan P1 yaitu 4,93 (agak suka). Rasa manis marshmallow terung belanda dipengaruhi oleh total gula yang dihasilkan. Semakin banyak bubur buah terung belanda 
yang ditambahkan maka rasa marshmallow yang dihasilkan semakin agak asam.

\section{Penerimaan keseluruhan}

Hasil analisis ragam uji hedonik marshmallow menunjukkan bahwa pengaruh penambahan bubur buah terung belanda berpengaruh sangat nyata $(\mathrm{P}<0,01)$ terhadap penerimaan keseluruhan marshmallow. Tabel 4 menunjukkan bahwa nilai rata-rata tingkat kesukaan panelis terhadap penerimaan keseluruhan marshmallow berkisar antara 4,67 (agak suka) sampai dengan 5,73 (suka). Nilai rata-rata tertinggi diperoleh pada perlakuan P2 yaitu 5,73 (suka), sedangkan nilai rata-rata terendah diperoleh pada perlakuan P6 yaitu 4,67 (agak suka). Secara keseluruhan panelis dalam memberikan penilaian terhadap marshmallow yang dihasilkan menunjukkan bahwa semua perlakuan penambahan bubur buah terung belanda dapat diterima oleh panelis. Selain itu, penilaian penerimaan keseluruhan panelis dipengaruhi oleh beberapa faktor seperti warna, aroma, tekstur dan rasa pada marshmallow.

\section{KESIMPULAN DAN SARAN}

\section{Kesimpulan}

Berdasarkan hasil penelitian dapat disimpulkan sebagai berikut ;

1. Penambahan terung belanda berpengaruh sangat nyata $(\mathrm{P}<0,01)$ terhadap kadar air, kadar abu, total antosianin, vitamin $\mathrm{C}$, total gula, uji kekenyalan, uji skor warna, uji skor rasa, uji skor tekstur, aroma dan penerimaan keseluruhan serta berpengaruh tidak nyata terhadap uji hedonik warna dan uji hedonik rasa.

2. Penambahan terung belanda $30 \%$ mampu menghasilkan marshmallow dengan karakteristik terbaik dengan kriteria kadar air 19,44\%, kadar abu $0,08 \%$, total antosianin $0,44 \mathrm{mg} / \mathrm{L}$, vitamin $\mathrm{C} 8,20 \mathrm{mg} / 100 \mathrm{~g}$, total gula $75,15 \%$, kekenyalan $1,47 \mathrm{~N}$, warna (agak merah muda dan agak suka), aroma (agak suka), tekstur (sangat kenyal dan suka), rasa (manis dan agak suka), penerimaan keseluruhan (suka).

\section{Saran}

Berdasarkan hasil penelitian, untuk menghasilkan marshmallow terbaik disarankan menggunakan perlakuan penambahan terung belanda $30 \%$ dan perlu dilakukan penelitian lebih lanjut mengenai daya simpan marshmallow.

\section{DAFTAR PUSTAKA}

Anonimus. 2008. BSN (Badan Standardisasi Nasional). SNI 3547.2:2008. http://sisni.bsn.go.id. Diakses pada tanggal 15 Februari 2016

Anonimus. 2013.2 Marshmallow. http://www.scribd.com. Diakses pada tanggal 25 Februari 2016

Arinaldo, B. 2011. Pengaruh Penambahan Konsentrasi Asam Asetat pada Pelarut Etanol Terhadap Efektivitas Ekstraksi Zat Warna Antosianin Terung Belanda. Jurusan Teknologi Hasil Pertanian. Fakultas Teknologi Pertanian. Universitas Andalas, Padang.

Bangun, E.Y.P. 2010. Pengaruh Perbandingan Jumlah Tepung Ketan dan Terung Belanda terhadap Karakteristik Dodol. Jurusan Ilmu dan Teknologi Pangan, 
Fakultas Teknologi Pertanian. Universitas Udayana.

Budi, S. 2006. Manfaat Terong Belanda. http://www.budiboga.com. Diakses pada tanggal 23 november 2017

Diniyah, N., T. Susanto, dan F. Choirunnisa. 2010. Uji Stabilitas Antosianin pada Terung Belanda. Jurnal Agrotechno. 1: 9.

Fitrina, F. 2014. Rasio Lidah Buaya dan Rumput Laut terhadap Mutu Permen Jelly. Fakultas Pertanian. Universitas Riau, Riau

Ginting, N., A. H. Rusmarilin., dan R. Nainggolan. 2014. Pengaruh Perbandingan Jambu Biji Merah dengan Lemon dan Konsentrasi Gelatin terhadap Mutu Marshmallow Jambu Biji Merah. Program Studi Ilmu dan Teknologi Pangan Fakultas Pertanian USU Medan. Medan.

Giusti, M.M. and R.E. Wrolstad. 2001. Characterization and Measurement of Anthocyanins by UV - Visible Spectroscopy. John Wiley and Sons, Inc.

NewYork.(http://www.academia.edu/6 873755/Characterization_and_Measur ement_of_Anthocyanins_by_UV-

Visible_Spectroscopy). Diakses pada tanggal 12 Maret 2016

Gomes, K. A. dan A. A. Gomes. 1995. Prosedur Statistik Untuk Penelitian Pertanian. UI Press. Jakarta.

Harsojuwono, B.A., I.W. Arnata., dan G.A.K.D. Puspawati. 2011. Rancangan Percobaan. Lintas Kata, Malang.

Hernani dan Rahardjo. 2005. Tanaman Berkhasiat Antioksidan. Penebar Swadaya. Jakarta.

Kumalaningsih, S. dan Suprayogi, 2006. Tamarillo (Terung Belanda). Trubus Agrisarana, Surabaya.

Nakai, S., dan Modler HW. 1999. Foods Proteins, Processing Application. London :Wiley-VHC.
Pratama, S. B., S. Wijana., dan A.F. Mulyadi. 2013. Studi Pembuatan Sirup Tamarillo (Kajian Perbandingan Buah dan Konsentrasi Gula). Jurusan Teknologi Industri Pertanian. Fakultas Teknologi Pertanian. Univeritas Brawijaya, Malang.

Sartika, D. 2009. Pengembangan Produk Marshmallow dari Gelatin Kulit Ikan Kakap Merah. Skripsi. Fakultas Pertanian. Institut Pertanian Bogor, Bogor.

Silaban, S. D., E. Prishanti., dan E. Saptaningsih. 2013. Pengaruh Suhu dan Lama Penyimpanan terhadap Kandungan Total Asam, Kadar Gula serta Kematangan Buah Terung Belanda (Cyphomandra Betacea Sent.). Lab Biologi dan Struktur Fungsi Tumbuhan Jurusan Biologi FSM. UNDIP. Semarang.

Soekarto, S. T. 1985. Penilaian Organoleptik untuk Industri Pangan dan Hasil Pertanian. Jakarta. Penerbit Bhratara Karya Aksara

Sudarmadji, S., B. Haryono, dan Suhardi. 1997. Analisa Bahan Makanan dan Pertanian. Liberty. Yogyakarta.

Syukroni, I. K. Yuliati dan A. Baehaki. 2013. Karakteristik Nata De Seaweed (Eucheuma Cottoni) dengan Perbedaan Konsentrasi Rumput Laut dan Gula Aren. Program Studi Teknologi Hasil Perikanan Fakultas Pertanian Universitas Sriwijaya Indralaya. Palembang.

Wati. A. S. 2003. Formulasi Serbuk Minuman Markisa Ungu (Passiflora edulis $f$ edulis. Sims) Dengan Metode Pencampuran Kering. Skripsi. Fakultas Pertanian. Institut Pertanian Bogor. Bogor.

Winarno, F.G. 2004. Kimia Pangan dan Gizi. PT. Gramedia Pustaka Utama : Jakarta. 